No. 12 - Papers of the

East-West Communication Institute

\title{
COMMUNICATION AND CHANGE \\ IN \\ DEVELOPING COUNTRIES
}

EAST-WEST CENTER

1777 East-West Road

Honolulu, Hawaii 96822 
THE EAST-WEST CENTER is a national educational institution established in hawaii by the United States Congress in 1960. Formally known as "The Center for Cultural and Technical Interchange Between East and West, "the fedexally funded Center is administered in cooperation with the University of Hawaii. Its mandated goal is "to promote better relations between the United States and the nations of Asia and the Pacific through cooperative study, training, and research."

Each year about 1,500 men and women from the United States and some 40 countries in the Asian/Pacific area exchange ideas and cultural insights in Center programs. Working and studying with the multinational Center staff on problems of mutual East-West concern, participants include students, mainly at the postgraduate level; Senior Fellows and Fellows with research expertise or practical experfence in such fields as government, business administration or communication; mid-career professionals in non-degree study and training programs at the teaching and management levels; and authorities invited for international conferences and seminars. These participants are supported by federal scholarships and grants, supplemented in some flelds by contributions from Asian/Pacific governments and private foundations.

A fundamental aim of all East-West Center programs is to foster understanding and mutual respect among people from differing cultures working together in seeking solutions to common problems. The Center draws on the resources of U.S. mainland universities, Agian-Pacific educational and governmental institutions, and organizations in the multi-cultural State of Hawaii.

Center programs are conducted by the East-West Communication, Culture Learning, Food, Population, and Technology and Development Institutes; Open Grants are awarded to provide scope for educational and research innovation, including emphasis on the humanities and the arts.

THE EAST-WEST COMMUNICATION INSTIT UTE concentrates on the use of communication in economic and social development and in the sharing of knowledge across cultural barrfers. The Institute awards scholarships for graduate study in communication and related disciplines, primarily at the University of Hawaii; conducts a variety of professional development projects for communication workers in specialized fields of economic and social development; invites Fellows and visiting scholars to the Center for study and research in communication and to help design projects; offers Jefferson Fellowshlps for Asian, Pacific, and U.S. journalists for a semester at the Center and the University of Hawail; conducts and assists in designing and carrying out research; arranges conferences and seminars relating to significant topics in communication; conducts a world-wide Inventory-Analysis of support, services, and country program needs in communication programs; assembles relevant communication materials with emphasis on Asian and Pacific material and makes these avallable for students, scholars, and practitioners at the Center and elsewhere; and publishes papers, reports, newsletters, and other materials emanating from the above activities.

\section{EAST-WEST COMMUNICAT ION INSTIT UTE}

- Wilbur Schramm, Director

- Virginia Jamieson, Publications Officer 
COMMUNICATION AND CHANGE IN DEVELOPING COUNTRIES

by

EVERETT KLEINJANS

July 1975

Papers of the East-West Communication Institute 1777 East-West Road, Honolulu, Hawaii 96822 


\section{ABSTRACT}

These remarks were made as part of the keynote speech to participants at the East-West Communication Institute conference "Communication and Change --Ten Years After" held in Honolulu January 13-17, 1975.

EVERETT KLEINJANS is President of the East-West Center, Honolulu, Hawaii. 


\section{COMMUNICATION AND CHANGE IN DEVELOPING COUNTRIES}

Behind the topic "Communication and Change in Developing Countries" lies the assumption that a relationship exists among the three factors--communication, change, and development. There may be a high correlation between communication and change; the more communication the more change, and the less communication the less change. Or possibly, the more communication, the more change, the more development there is. However, we know that change is not necessarily development. Change can be either positive or negative, while development connotes something positive, like progress. Certainly, people prefer development, not mere change.

The people of Asia and the Pacific have struggled mightily over the past quarter century to develop their countries. Their development has been encouraged and aided by some of the more affluent countries through programs of technical assistance and educational exchange. Development has taken place, therefore, within a framework of intermational relations, and, for our purposes, East-West relations. The establishment of large international institutions such as the World Bank, the Asian Development Bank, and the United Nations Development Program indicates the international nature of development. During this quarter of a century great changes have taken place; the perceptions of those changes affect our ability to communicate with and relate to each other. The purpose of this paper is to outline briefly my perceptions of these changes in East-West relations and development and to suggest some implications of these changes.

Our perceptions of the world are extraordinarily important for they determine our attitudes and affect our behavior. * In fact, our image of reality determines what we see. In The Structure of Scientific Revolutions, Thomas S. Kuhn, a historian of science, traces the changes that have taken place in the paradigms of the world of science. A paradigm is the rather large constellation of beliefs, values, and techniques shared by the scientific community which, at the time it is current, specifies the kind of entities the world contains or does not contain. It elucidates what the world is like and hence what scientists search for. When the paradigm changes, people's views of and reactions to the world are changed. As Kuhn states:

* Of course, our attitudes and behavior also determine our perceptions. However, for the purposes of this paper we will proceed from perceptions. 
Examining the record of past research from the vantage of contemporary historiography, the historians of science may be tempted to exclaim that when paradigms change, the world itself changes with them. Led by the new paradigm, scientists adopt new instruments and look in new places. Even more important, during revolutions scientists see new and different things when looking with familiar instruments in places they have looked before . . . What a man sees depends both upon what he looks at and also upon what his previous visualconceptual experiences have taught him to see. In the absence of such training there can only be, in William James' phrase, 'a bloomin' buzzin' confusion.' (Pp. 111, 113, emphasis added.)

Thus scientists perceive the world through their paradigmatic glasses. In the same way, the culture in which people are raised is a kind of paradigm that tends to determine what they look for and therefore what they see. Ernst Cassirer, the philosopher of symbolic forms, advanced the view that facts do not become thought until they pass through the symbolic system which the perceiver of the facts possesses by virtue of his culture. In An Essay on Man he says:

No longer in a merely physical universe, man lives in a symbolic universe. Language, myth, art, and religion are parts of this universe . . . No longer can man confront reality immediately; he cannot see it, as it were, face to face. Physical reality seems to recede in proportion as man's symbolic activity advances. Instead of dealing with the things themselves man is in a sense constantly conversing with himself . . His situation is the same in the theoretical as in the practical sphere. Even here man does not live in a world of hard facts, or according to his immediate needs and desires. He lives rather in the midst of imaginary emotion, in hopes and fears, in illusions and disillusions, in his fantasies and dreams. "What disturbs and alarms man," said Epictetus, "are not the things, but his opinions and fancies about the things." (P. 43.)

Each culture, by providing a language, a set of myths, art, and religion, defines human experience and its meaning for its inhabitants. In that sense culture prejudices what we see and how we interpret what we see. Likewise, perceptions of East-West relations and development will restrict what people look for and see, what meaning they give to "events," and how they behave and communicate. It is necessary to have clear perceptions so 
that when people East and West look at each other they will avoid William James' "bloomin' buzzin' confusion," and be able to communicate and relate with more understanding.

Relations between and among nations are really relations between and among different images, perceptions, myths, and ideas which people have acquired through experience. During World War II, for example, China was the good friend of the United States and Japan its great enemy. Within four years after the end of that war, those images had been completely reversed. Americans perceived Japan as a good friend and China (the People's Republic) as a great enemy. Possibly still more important is the fact that perceptions of past events, persisting through memory, provide a prism through which subsequent events are diffracted. During the post-World War II period, leaders in the United States saw the People's Republic of China and Soviet Russia as analogues of Fascist Germany and Italy. Merle Miller, in his oral biography of Harry S. Truman, Plain Speaking, quotes the former president on his perception of the North Korean invasion of South Korea,

And it was always the same, always had the same results. Hitler and Mussolini and the Japanese were doing exactly the same thing in the $1930^{\prime} s$. . . The strong got away with attacking the weak, and I wasn't going to let this attack on the Republic of Korea. . . go forward. Because if it wasn't stopped, it would lead to a third world war, and I wasn't going to let that happen. Not while I was president.

(Pp. 293-294.)

So the image of Munich and Chamberlain and the appeasement that led to World War II, by affecting President Truman's perception of the invasion of South Korea, influenced and justified his behavior. Similar analogies were used during the Vietnam War.

On the other hand, General Lin Piao of the People's Republic of China revived the image of the Japanese invasion of China when he talked about the United States. Because the Japanese had been imperialistic and the Chinese had fought and defeated them, he was convinced that the Chinese must fight the American imperialists and defeat them in the same way, using the same tactics. Thus the images that people carry around in their minds tend to determine how they perceive events and how they behave.

It is not, however, only the leaders of a country who determine the policies toward other countries. More and more often the common man-especially the informed common man--has an impact upon the decisions of his government. Of course, his actions also are guided by his perceptions, which, in turn, are shaped by vicarious experience made possible by the 
communication media. News stories are played up or down according to an editor's perception of the world. Where a society is closed, the government, by manipulating the media, shapes those perceptions. Furthermore, although the world is changing quickly, people's memories are more constant. In recent months I talked with a contractor in Honolulu who, when he heard that I had lived in Japan a long time, proceeded to tell me all about the Japanese--how bad they were to have attacked and fought us, and how well Americans had treated them; how the Japanese could not be trusted as the Americans could be. Where did he get his information, I asked. World War II and the American occupation. Such perceptions ultimately have impact upon policy and upon relations, for they are often shared by many people with similar memories.

Not only do our images of one another affect public policy, but the concept of development itself influences our perceptions of other nations. The people of the West, for example, may see the people of developing countries as "in need of our know-how, " or the "white man's burden." Our behavior East and West will be determined by such perceptions. It is therefore necessary that our East-West perceptions correspond as closely as possible to the changes that have taken place. This presentation is an attempt to further the process of squaring perceptions with reality. The time period with which I am concerned here is the postWorld War II era. Others may want to analyze and correct these perceptions where they see that my images do not correspond with reality as they perceive it.

First, during the post-World War II period the world has changed from a basically bi-polar world of ideology to a multi-lateral world of multi-faceted problems. Although ideology still plays a role in international relationships, it certainly is not as dominant as it was in the late forties, the fifties, and the sixties when the clash between capitalism and communism was at its peak. Today, world problems dominate. We see some 80 million people added to the world annually. Hunger and malnutrition are rampant. Inflation-cum-recession is threatening the economy of the entire world. Super-affluence and rapid consumption threaten the supply of resources. Pollution endangers our environment and overcrowding menaces the life of our cities. All countries face these and other problems, but no ideology has magic solutions for them. The problems must be solved. In an article in Scientific American, September 1974, Ansley Coale predicted that "in less than 700 years" if the present population growth rate continues geometrically, "there would be one person for every square foot on the surface of the earth." ("The History of the Human Population," pp. 41-51.) Of course, the population problem will be solved one way or the other before we get that far--through famine or violence or through intelligent cooperation. The point is that today problems, rather than ideology, predominate. 
Second, World War II changed the axis of East-West relations from the vertical one of colonialism to a more horizontal one among autonomous nations. However, the relationships were not among equals. The United States emerged from the war strong and relatively unscathed; the countries devastated by war needed rebuilding; those recently established needed development. In this situation the West, especially the United States, provided technical assistance for the building and rebuilding. Al though at its best it was an altruistic gesture, this assistance created a donorrecipient relationship, with the West feeling the ego-enhancing glow from the ability to help and the East experiencing the ego-deflating pain of constant need. Although it is legitimate, even ethically imperative, for more affluent countries to assist less affluent ones, this technical assistance syndrome has to be a transition stage, for it does not build good human relationships. In fact, one of the greatest sins of Western man has been to equate his material and technological progress with a sense of moral superiority. Even such a prominent international philosopher as F.S.C. Northrop expresses this superiority in his now famous book, The Meeting of East and West, when he says:

Ours is a paradoxical world. The achievements which are its glory threaten to destroy it. The nations with the highest standard of living, the greatest capacity to take care of their people economically, the broadest education, and the most enlightened morality and religion exhibit the least capacity to avoid mutual destruction in war. (P. 1.)

Somehow, Mr. Northrop failed to ask why, if these nations have the least capacity to avoid war, they should be judged as having "the most enlightened morality." Upon what basis does he conclude that "the nations with the highest standard of living" have "the most enlightened morality and religion"? Were his perceptions bounded by his cultural blinders?

Probably the most important task of development is that of fostering dignity and respect. All people in every country desire quality of life at home and equality of relations abroad. Not receiving the material goods one feels to be his due fosters anger; being looked down upon engenders hatred. The most basic component of East-West communication and cooperation for development must be human dignity and respect. Herein lies one goal of international communication.

The unfortunate deprecatory slant to East-West relationships is exacerbated by the inadequacy of language, especially when it struggles to discuss people outside our own group. At the East-West Center, for example, the term non-American is used for those of the staff and participants who come from outside the United States. Unfortunately, the term 
has a negative (non) connotation and puts the United States at the center of the relationship with all other countries measured in relationships to it. However, it is better than the terms foreigner or alien, which have a pejorative meaning. The situation is similar in other countries and with other languages: the phrases wai kuo ren in Chinese, gaijin in Japanese, or auslander in German all have unfavorable connotations. We human beings still have not created vocabularies that denote and connote relationships of mutuality, collegiality, and respect for members of other groups. Phrases like "technical assistance" and "underdevelopment" are not adequate either. The challenge here is for a linguistic creativity that will help to move the axis of East-West relationships toward the horizon of equality, respect, and dignity.

Third, although a vast number of independent nations have arisen since World War II and nationalism is stronger today than ever, the nations of the world are of necessity becoming more and more interdependent. In fact, it is becoming more difficult to separate national domestic affairs from international affairs. The search for energy and raw materials, the devaluation of the dollar, the extinction of whales, the use of communication satellites, the conduct of the Vietnam War, the formation of transnational corporations, all these and more are evidence that we live in an interdependent world wherein nations not only do but must interact as never before. No nation is an independent island of self-sufficiency.

Fourth, all countries are developing countries. Development has too long been thought of in economic terms alone. I define development as the process through which a society moves to acquire the capability of enhancing the quality of life for its people, primarily through the solution of its problems. In this sense, the United States and other "affluent" countries are underdeveloped; they lack the capabilities to solve problems of urban life, environmental pollution, crime, and other social problems. The fact is that every country has areas it needs to develop and may be aided in the task by other countries and cultures that face similar problems. Since all countries are developing, they can all learn from each other.

Fifth, the task of developing a country must ultimately be undertaken by the inhabitants of that country. The idea, current during this post-war period, that more affluent countries are obliged to assist less affluent countries, was a new concept and therefore had its pitfalls as well as its virtues. We have now learned that any nation which wants to develop, that is, to improve the quality of life of its people, must do so itself, although not necessarily alone. Science and technology can be borrowed, imported, or adapted from abroad, but creativity from within a country is crucial. The local creation of a better way to pump water from one rice 
paddy to another, or to thresh the grain once it is harvested may do more for development than the importation of an automobile factory or a cement plant. For development ultimately is not a matter of technology or gross national product, but the attainment of new knowledge and skills, the growth of a new consciousness, the expansion of the human mind, the uplifting of the human spirit, the infusion of human confidence.

Sixth, there is a difference between development and reconstruction. During Worid War II countries like Germany, England, and Japan vere devastated by bombing. But with money pumped into their politico-economic systems after the war these societies soon got back on their feet. People began to believe that all that was needed for societies to gush forth with economic goodies was financial pumpmpriming. However, the societies recently liberated from colonialism did not respond in the same way. They did not have the organizational infrastructure or the skilled personnel of the industrialized nations. Often local elite had been trained only to carry out the functions of the colonial government, and none of them had functioned at the top levels of management. Furthermore, the leaders who emerged with the end of colonialism were generally those who had fought the colonial power. They had been highly successful in mobilizing anticolonial sentiments. But arousing the motivation to expel the colonizer is not the same as stimulating the needed energy to develop the country. The tasks of development are quite different from the tasks of either reconstruction or of gaining independence.

Seventh, the drive for economic development has not resulted in political development, at least not in the Western democraic sense. Political development has generally been conceived by Westerners as requiring participation of the common man in politics, the capacity of the political system to produce beneficent change, the open and free flow of ideas, the right of the individual to make choices with minimum restriction or interference, and the means of effecting transfer of power peaceably. The factors involved are too many to go into here. However, it is evident that neither technical nor military assistance guarantees a democratic process, nor does it "buy" governments. Furthermore, the achievement of economic development requires planning, and planning and freedom, although not antithetical, are not completely compatible. Plans put limitations on people and need authority for their implementation. This authority is generally centralized, often in the hands of those trained for command, the military. The more centralized socialist form of government often has more appeal to people in Asia than the decentralized, more participatory form of government evidenced in the West. Westerners must either adjust their definition of political development or acknowledge that economic and political development are not necessarily concomitant. 
Eighth, in the technological society good human relations are not only desirable but essential. Since World War II human beings both East and West have lived out more of their lives in man-made environments. For example, more and more people are flocking into cities, which are products of technology. Although there is the danger of enslaving ourselves to our technological devices, there is also the great possibility of getting these devices to work effectively for us, relieving us of some of the more tedious or back-breaking work. But man-made environments show certain important characteristics. They produce stress due to rapid change. The great cities of the world are industrial, communicative, and cultural synapses. It is in these cities that we find the factories and headquarters of huge businesses, the television and radio stations, the mass circulation newspapers, the international airports, the great universities, the great concert halls, theaters, and cathedrals. Newfangled gadgets, new styles, innovative ideas, and modern art first appear and gain acceptance in the great cities. The small towns that have been changed most over the years are those that have been incorporated into the orbit of expanding metropolises. More remote farm towns or villages have changed little. Man-made environments, manifested by our great cities, change most. This change places a great deal of stress upon human relations. In the big city, who gives a damn?

Crucial to good human relations in a man-made technological society is cooperation. If bus drivers, school teachers, telephone operators, or garbage collectors go on strike, a society can soon come to a virtual standstill. If a person fails to cooperate by forgetting to put gasoline into the car before going to work in the morning and then runs out of gas on a bridge or in a tunnel, cars will be backed up for miles and thousands of people will be late for work. In the technological society, whether or not people want it, cooperation is necessary.

Probably the most important element of good human relations, essential to the technological society, is trust. Life has always consisted of a promise-giving and promise-keeping set of relationships. "I will do my part if you do yours." Today we keep promises or extend trust without ever seeing the person at the other end of the promise, the one in whom we place our trust or who trusts us. People travel thousands of air miles without ever seeing the pilot who flies the plane or the crew that maintains it. In The Untitled Poem on the History of Industrialization, R. Buckminster Fuller speaks of the mutual trust needed in modern society. He describes this through a man on an express train hurtling along:

with unuttered faith that

the engineer is competent

that the switchmen are not asleep, 
that the track walkers are doing their job,

that the technologists

who designed the train and the rails

knew their stuff

that thousands of others

whom he may never know by face or name

are collecting tariffs,

paying for repairs,

and so handling assets

that he will be paid a week from today

and again the week after that,

and that all the time

his family is safe and in well-being

without his personal protection.

(Quoted in Bucky by Hugh Kenner, pp. 226-227.)

Ninth, another change in modern society is the fantastically rapid increase of knowledge and the human activity involved in research, data processing, information storage and retrieval, mass education and mass communication. In fact, knowledge proliferates at such a rate that a scholar finds it difficult to keep up even in his own field of specialization, to say nothing of related fields. In such a situation people from different fields with different specializations are having to learn to communicate and work together, especially in attempts to apply knowledge toward a solution of some of the practical problems mentioned earlier. Without cooperation among people from different disciplines, from different professional groups, and, of course, from different cultures and societies, solutions will never be found. During the past quarter of a century we have become aware as never before that no one person can know everything, nor, on the other hand, can one person merely do one thing. All acts are interrelated. New strains of rice and bigger crops may solve one problem but create others. The damming of a river may provide hydroelectric power, but it may also upset the ecology of the surrounding country. How can people be foresighted and sensitive to the ramifications of their decisions? "By their fruits you shall know them" can be applied as much to the results of human decisions as to the behavior of men of faith. Because knowledge proliferates so fast and its applications have such far-reaching results, communication and cooperation among people of all walks of life is imperative.

Tenth, development is associated not only with rapid increases in knowledge and its communication, but it also affects ethics and values and impinges upon religion. The anguishing problem of poverty, that human 
the central values which were favorable to industrialization is at least a strong possibility. (P. 194.)

The role of religion in either impeding or stimulating change in developing countries is thus a vital issue.

Not only should people be concerned with the impact of religion on the process of development, but also with the introduction of industrial technology, managerial techniques and the scientific method on religion. One of the most famous trials in the United States, the Scopes trial, in which a young school teacher was tried for teaching Darwin's theory of evolution, demonstrates the possible explosiveness of the encounter between certain kinds of religion and changing scientific ideas. One wonders if, when, and where the analogue of the Scopes trial will take place in the preinchustrial societies. The scientific method with its basic skepticism challenges traditional explanations for the causes of natural phenomena. What was experienced as a kind of comfortable divine destiny now enters the disturbing arena of human choice. Old meanings are lost and human relations come unglued. In The Homeless Mind, the authors describe the impact of technology, bureaucracy, and the resulting pluralization of lifeworlds in moderm society. They say:

The pluralization of social life-worlds has a very important effect in the area of religion. Through most of empirically available human history, religion has played a vital role in providing the overarching canopy of symbols for the meaningful integration of society. The various meanings, values and beliefs operative in society were ul timately "held together" [by religion which] can be defined as a cognitive and normative structure that makes it possible for man to feel "at home" in the universe. (P. 79.) Modern man has suffered from a deepening condition of "homelessness." (P. 82.)

Such loss of meaning and values has a profound impact upon the ability of people to think about change and development or to participate in the process of development. It is evident that development is intimately related to values, ethics, and religion.

The perceptions listed above are all perceptions of change: change in the interactions among nations, change in the world in which this interaction is taking place, change in perceptions of development itself and in the inter relationship among development, values, and religion. Whether national interaction will be beneficent or maleficent, whether actions taken to solve human problems will be peaceful or violent, whether man- 
condition toward which development is directed, cannot be legitimately discussed without ethical considerations. Food for one's self may raise economic or biological questions; food for those who have too little challenges one with ethical questions.

If development is to succeed, values such as frugality, punctuality, accountability, and the postponement of present pleasure for some future good must be inculcated. Very often these new values conflict with traditional ones. Frugality and the postponement of present pleasure may conflict with the joy of a fiesta, and punctuality can destroy conviviality. Development is a soothing concept, but it is not a painless process. Peter Berger and his co-authors in their book The Homeless Mind (p. 7) discuss the moral problem faced when people decide to develop. They say, "We believe that the most important question facing anyone responsible for 'development' is, how much human suffering is acceptable to achieve certain economic goals?" Their question presents people with a moral dilemma, for it raises the similarly important but opposite question: how much human suffering is acceptable if certain economic goals are not achieved?

Finally, religion must be included in any consideration of development. Across time religions have been a potent source of cultural values, a centripetal force of social cohesion. The members of modern societies need to have a common set of beliefs, values, and expectations if their societies are to operate well. For many people, gods and value systems are one and the same thing. Regardless of definitions, two questions became important as we consider changing perceptions: how does religion relate to development, and what is the impact of development on religion?

Max Weber's famous book The Protestant Ethic and the Spirit of Capitalism raised the question of the relation of religion to the socioeconomic world. The question has still not been satisfactorily answered. Each new generation of scholars sees it as a challenge. Gunnar Myrdal in his monumental work Asian Drama says, "The writer knows of no instance in present-day South Asia where religion has induced social change" (p. 103). On the other hand, Robert N. Bellah, writing about the relation of religion and the rise of Japanese capitalism in his book, Tokugawa Religion, concludes

that religion played an important role in the process of political and economic nationalization in Japan through maintaining and intensifying commitment to the central values, supplying motivation and legitimation for certain necessary political innovations and reinforcing an ethic of inner worldly asceticism which stressed diligence and economy. That it may also have played an important part in the formation of 
kind will see commonalities and move toward unity or see differences and revert to tribalism will depend upon our perceptions and our behavior based upon those perceptions. Today as never before, educating people to communicate and cooperate in an attitude of mutuality, equality, and respect both within and across national and cultural boundaries has become a necessity. The condition of the world demands that people act affirmatively toward each other and work to improve the human condition both at home and abroad. People work within their own national boundaries as nationalists, and across national boundaries as cosmopolitans. In other words, the world needs cosmopolitan nationalists.

The phrase "cosmopolitan nationalism" is in a sense a contradiction in terms, like "broad narrowness." Nationalism in its better sense means patriotism, the love of country, of the fatherland, of forefathers--patriotism being derived from the Latin word patrios meaning "of our father." However, nationalism can take extreme forms such as the excessive or blind patriotism that is called "chauvinism." Beyond chauvinism lies jingoism, an arrogant nationalism, especially associated with belligerence in one's policies toward other countries. It is associated with another concept, xenophobia, which is a fear or hatred of foreign things, foreigners, or anything strange.

In its extreme form nationalism is quasi-religious. Paul Tillich has defined religion as "the state of being grasped by an ultimate concern, a concern which qualifies all other concerns as preliminary and which itself contains the answer to the question of the meaning of our life" (Christianity and the Encounter of the World Religions, p. 4.). If sacrificing one's life for a cause is behavior expressing ultimate concern, then we would have to acknowledge that in the twentieth century more people have died for the quasi-religion of nationalism than for any other cause. Nationalism gathers to itself all the symbols of a religion--flags, anthems, hymns, the quietness of awe at national monuments or cemeteries. Nationalism must be qualified by cosmopolitanism.

Cosmopolitanism, of course, is the opposite of nationalism. It can degenerate into love for an amorphous mass of humanity. I believe it was Herblock, the cartoonist, who put its essence into a cartoon of a man saying, "I love humanity. I hate people." It is often easier to love someone on the other side of the world than to help a neighbor. The parable of the good Samaritan in the Bible tells of the priest and the Levite who hurried by on the other side, more than likely on their way to some religious duty, leaving a wounded man stranded by the side of the road. They ignored the neighbor closest to them who needed help. The genuine cosmopolitan is a person marked by interest in, familiarity with, and appreciation of many parts of the world. Or, to put it negatively, a cosmopolitan is not provincial, local, limited, or restricted by the attitudes or interests or loyalties of a single region, people, or sphere of activity. 
The question is whether nationalism and cosmopolitanism can be married. For the good of the present world they must be wed. However, that nationalism should be of the positive kind expressed through concern for the people from whom one springs and who are close at hand. And that cosmopolitanism must be of the kind that extends to outsiders, individually and collectively, the care one extends to one's own kind. Certainly, within the great surge of activity that we call development, nationalism in the sense of loving care and devoted labor given to the improvement of the quality of life for those around us is a positive force. "Cosmopolitan nationalism" goes further. It is the willingness and ability not only to hold values and beliefs of our own and to work for the improvement of the quality of life in our own situation, but also to recognize that others also have values and beliefs which, although different from ours, are as valid as ours, and that they, too, are working for the improvement of the quality of life where they live. "Cosmopolitan nationalism" expresses itself further in the willingness and ability to join people of other nations in their efforts to improve the quality of life. In fact, as it becomes more and more apparent that we must cooperate to improve the quality of life upon our planet, we see that "cosmopolitan nationalism" is not only nice, but necessary.

"Cosmopolitan nationalists" grow and thrive as a product of dialogue among nations and civilizations. Such an international encounter can take place only if people consider other human beings and their cultures as being part of themselves. Somehow we must come to realize that we are part of each other's history, that separation makes us islands, while living with care for others can fill the emptiness in each of us. Through knowing and honoring other people we can discover new dimensions, new perceptions of the world. If anything is exciting about the emerging world of the twentyfirst century, it is the prospect of living in and being enriched by the diversity of this world, and becoming more broadly human through the experience.

We have come to a point in history when we must ask whether a person who knows only his own country is completely human. If a Japanese is only Japanese, a Filipino only Filipino, and American only American, is she or he a complete human being? When historians look back upon this time perhaps they will see it as the time in which the development of "cosmopolitan nationalism" took place. But they will also notice that people did not discover it the way Columbus discovered America. It cannot be discovered. We must make it.

One of the important tasks that communicators can perform for development is to create more accurate perceptions of our respective countries, and to keep open the lines of communication between them. The concept of development and its processes and the accompanying 
language and values must also be thoroughly studied, well delineated, and accurately communicated. Through this process many people will have acquired knowledge and skills, perceptions, and attitudes, with which they will be able to work not only in their own society but also in other countries and cultures. These "cosmopolitan nationalists" will give the human race a better chance to live with greater quality of life on this planet. 
BIBLIOGRAPHY

Bellah, Robert N. Tokugawa Religion. Glencoe, Illinois: The Free Press and the Falcon's Wing Press, 1957.

Berger, Peter, Brigitte Berger, Hansfried Kellner. The Homeless Mind, Modernization and Consciousness. New York: Vintage Books, 1973.

Cassirer, Ernst, An Essay on Man: An Introduction to a Philosophy of Human Culture. Garden City, New York: Doubleday and Company, Inc. , 1956.

Coale, Ansley, "The History of Human Population," Scientific American, Volume 231, Number 3 (September 1974).

Eisenstadt, S. N. The Protestant Ethic and Modernization. New York, London: Basic Books, Inc., 1968.

Heilbronner, Robert L. The Great Ascent: The Struggle for Economic Development in our Time. New York: Harper and Row, Publishers, 1963.

Iriye, Akira. Across the Pacific: An Inner History of American-East Asian Relations. New York: Harcourt, Brace and World, Inc., 1967.

Kenner, Hugh. Bucky: A Guided Tour of Buckminster Fuller. New York: William Morrow and Company, Inc., 1973.

Kuhn, Thomas S. The Structure of Scientific Revolutions. (Second edition, enlarged.) Chicago: The University of Chicago Press, 1970.

Miller, Merle. Plain Speaking: An Oral Biography of Harry S. Truman. New York: Berkley Publishing Corporation, 1974.

Myrdal, Gunnar. Asian Drama: An Inquiry Into the Poverty of Nations. New York: The Twentieth Century Fund, 1968. 
Northrop, F.S. C. The Meeting of East and West: An Inquiry Concerning World Understanding. New York: The Macmillan Company, 1960.

Tillich, Paul. Christianity and the Encounter of the World Religions. New York and London: Columbia University Press, 1963.

Van Leeuwen, A. T. Development Through Revolution. New York: Charles Scribner's Sons, 1970. 